\title{
Novel as a Stimulant in Instilling Empathy and Sympathy in Character Education: A Case Study of Arah Langkah, a Novel by Fiersa Besari
}

\author{
Dyah Prabaningrum ${ }^{1}$, Rahayu Pristiwati ${ }^{2}$, Sumartini $^{3}$, Sheila Zairoturaudloh ${ }^{4}$ \\ Department of Indonesian Language and Literature, Faculty of Languages and Arts, \\ Universitas Negeri Semarang, Indonesia ${ }^{1,2,3,4}$ \\ \{dyahprabaningrum@mail.unnes.ac.id ${ }^{1}$ \}
}

\begin{abstract}
Among the forms of communication is intercultural communication. Intercultural communication aims to share information between individuals or groups with different cultural backgrounds. This type of communication is used by both parties to understand each other and accept the differences in society. However, cultural intolerance in society often hinders intercultural communication. Such an issue can be minimized by promoting empathy and sympathy between communicators and communicants, thus resulting in a harmonious life, which resonates with the third principle of Pancasila. In this regard, sympathy and empathy are defined as a psychological condition representing tolerance acts to others. Each of these terms has their interpretations. Empathy [2] is described as a person's attitude when thinking about other people's feelings without losing self-identity, meaning that the person is neutral when responding to something. Sympathy, on the other hand, is how a person thinks about others or to take part in someone else's feelings with less self-identity attached to this process. At this point, the person or observer is no longer neutral. Many people are running out of sympathy and empathy. According to the data by Suara.com[1], 65 percent of people in today's modern society are losing their empathy. They argue that having too much empathy means that a person disregards rationality. Nevertheless, losing empathy signifies the loss of feeling or motivation to help one another. A recent study at Pennsylvania State University [1] reveals that the majority of people believe that being empathetic only drains their mental energy. Sympathy and empathy are a condition that forms the quality of being humane in oneself. Considering this, cultivating empathy and sympathy is necessary. Among the approaches to conceptualize this is character education. Learning literary work is one of the overarching and adaptive approaches in character education to cultivate the two attitudes for people who expect flexibility in learning and enjoyable experiences. In the present study, a novel entitled Arah Langkah by Fiersa Besari was selected to be the medium for instilling empathy and sympathy. The objective of the present work was to explore, through psychological criticism, the qualities of the two attitudes in the novel as a medium of character education. In this narrative research,the data were discussed using a hermeneutic approach. The result finds several qualities of
\end{abstract}


sympathetic and empathetic attitudes in the characters of the novel; these serve as the model for the readers in cultivating the attitudes.

Keywords: Literature Psychology, Character Education, Empathy, Sympathy

\section{Introduction}

Nowadays, many people have started to ignore empathy and sympathy. The data by Suara.com[2] show that 65 percent of people in today's modern society are losing their empathy. They believe that having too much empathy means that a person disregards rationality. However, losing empathy marks the loss of feeling or motivation to help one another. In a recent study at Pennsylvania State University [2], most people think that being empathetic only drains their mental energy.

As a matter of fact, sympathy and empathy are a condition that forms the quality of being humane in oneself. Considering this, cultivating empathy and sympathy is necessary. Among the approaches to instill the characters is through character education. Learning literary work, specifically novel, is among many overarching and adaptive approaches of character education in cultivating the two attitudes for people who expect flexibility in learning and enjoyable experiences. Simply put, it is possible to teach empathy and sympathy by learning literary works. The key to this approach lies in the element of characters and characterizations of the novel. Suharianto [3] claims that these two elements are central to a story. Characterization represents any details regarding the characters of the story, including their inner and outer qualities, the perspective of life, attitude, faith, tradition, and other aspects. A reader can identify the attitude and expression of a character in a story by reading the details about other characters in the story. Further, the presence of characters forms a series of events in the story. Such events then develop the story as a whole.

Arah Langkah is a literary work whose storytelling heavily relies on the narration of the experience of the characters in perceiving Indonesia and its cultures[4]. The cultural aspects here are not only about something concrete but also abstract concepts. The importance of being empathetic and sympathetic is one of the abstract concepts seen in Arah Langkah[4]. Drawing upon the above discussion, the present work seeks to explore, through psychological criticism, the qualities of the two attitudes in the novel as a medium of character education. Some relevant studies have been conducted by Pramujiono[5], Vieco[6], Aertsen[7], and Putri[8]. Those studies contribute to raising the awareness that literary works hold the potential to be a medium of character education, especially in cultivating sympathy and empathy. Example diversification in the characters and characterizations of the novel are worth investigating, and thus these issues are the novelty of this research. In addition, the novel tells a story of several tribes from the western, middle, and eastern parts of Indonesia.

\section{Research Method}

This research relied on a psychological criticism approach. All data were examined using a hermeneutic method, i.e., a method that focuses on analyzing words, sentences, texts, and others to comprehend instructions in symbols of a text [9]. The data were retrieved from a novel entitled Arah Langkah by Fiersa Besari. A narrative method was applied in data analysis 
and interpretation. The analysis focused on identifying, through psychological criticism, the qualities of the two attitudes in the novel as a medium of character education.

\section{Results and Discussion}

Excellent literary works and artworks are the ones containing a value [10]. Such a value is embedded in the structure of a literary work; the value is implicitly incorporated in the plots, settings, characters, themes, and messages. Several values contained in a literary work include: (a) hedonic value that gives a pleasant experience to the readers; (b) artistic value that is capable of manifesting an art piece or skills in performing a particular work; (c) cultural value that depicts or contains an in-depth correlation between the literary work with society, civilization, and culture; (d) ethical, moral, and religious value that reflect advice or teachings related to these values; (e) practical value, or the value containing practical aspects that can be implemented in real life. A literary work is considered valuable if it has its aesthetic and moral values. These two aspects are found in Arah Langkah novel. In the novel, in addition to the moral values, one can also spot the beauty of diction carefully selected by its author, Fiersa Besari. The moral values incorporated in the novel are being empathetic and sympathetic; this can be seen in this scene: Baduy exchanged messages with a girl named Intan. He wanted to follow the group of the girl. However, Intan rejected the request since she thought that it would be unfair to others. At the end, Intan allowed the man and his two best friends to follow her group since Baduy insisted on joining Intan. Below is the excerpt depicting the situation:

"Di bibir pantai Jeneiya, Baduy bertukar pesan dengan gadis bernama Intan tersebut. Awalnya, Intan menolak kami untuk ikut rombongannya. Katanya, itu akan terkesan tidak adil pada anggota rombongan yang lain. Tapi karena Baduy terus memohon, Intan akhirnya mengizinkan kami untuk ikut, meski tentu saja kami harus tetap membayar beberapa ratus ribu."[11] (hlm. 140)

\section{English translation:}

At Jeneiya beach shoreline, Baduy exchanged messages with that girl named Intan. In the beginning, Intan did not want us to follow her group. She said that doing so would be unfair to the other group members. But Intan allowed us to come along because Baduy insisted on joining Intan's group, even though we need to pay"[11] (p. 140).

One can get the idea that Intan was empathetic to Baduy. She did not want to help the man. Yet, as Baduy begged her and understood his feelings, Intan gave the man a solution by allowing Baduy and his friends to follow her group. Central to nurturing sympathy is human feeling. Sympathy is defined as affective responses containing the feeling of grief and affection for others (without emotional sharing). Such a response indicates the situation in which the observant perspective becomes one with other people, thereby eliminating selfidentity. In other words, the observant is no longer neutral. The dialogue excerpt below shows how Bung is unable to contain his sadness before the parting with Prem.

"Bung, maaf, ya, kalau aku banyak salah,"

Perpisahan ini terlalu formal. Aku memeluknya tanpa bisa mengucapkan apa pun. Perasaanku hancur melihat Prem mengambil langkah untuk pulang. Sudah 
beberapa kali aku membujuknya agar ia tetap ikut petualangan ini seperti janji kami waktu itu, tapi Prem tetap pada pilihannya. Gadis itu menepuk punggungku. [11](hlm.260)

\section{English translation:}

"Bung, I'm sorry if I make any mistakes."

This parting is way too formal. I hugged her without saying anything. I've never felt so gloomy, hearing Prem's decision to go home. I've tried million times, persuading her to continue our journey as we have promised that time, but still, Prem still goes with her choice. She patted my back [11] (p.260).

The situation depicted in the above excerpt reveals the despondency of Bung, knowing that Prem would go back to her hometown. His sadness is shown in the way he hugged Prem, although he did not express his feeling verbally. The way Bung responded indicates the feeling of sorrowfulness that he concealed when Prem bid farewell. The act of being sympathetic is also seen whenever a person hears news; for example, a person would feel sad if $\mathrm{s} /$ he hears sad news. This notion is depicted in the story when Bung and Prem attended a traditional funeral in Tana Toraja. Although both of them never meet with the deceased's family, Bung and Prem express their condolences to the family to support them.

Kulihat istri yang ditinggalkan berusaha tegar meski matanya begitu sembap. $\mathrm{Ah}$, siapa pula yang kuat ditinggalkan sang kekasih? Meski tak saling kenal, aku dan Prem bersalaman dengan ibu tersebut, menguatkannya meski hanya lewat kata-kata[4] (hlm. 160)

\section{English translation:}

I saw the wife tries to stay tough, although I notice her puffy eyes. I know, who in the world would be so tough after the passing of their loved one? Although we never meet with her, Prem and I greeted the woman, supporting her even with just the words of condolences [4] (p.160).

The above excerpt illustrates the way Bung and Prem expressed their condolence to the deceased's family. The expression of condolence is the factor that stirs Bung and Prem's sympathy for the loss of the wife's husband. Although they never meet each other, the emotional condition of Bung and Prem was so strong that it drove them to support the woman. In general, sympathy is a psychological process related to the feeling of understanding other people or groups [12]. Such a feeling is based on several aspects, e.g., attitudes, appearances, personal conditions, events, and others. There are other contributing factors to expressing sympathy, such as the willingness to understand, help, and work with other people. All of these notions are found in Arah Langkah. When Bung and his two companions made a beach tent, a man wanted to help the gang, indicating his act of being empathetic. Below is the excerpt of the story illustrating aforementioned situation.

Tatkala aku mengeluarkan alat makan dari dalam ransel, seorang pemuda lokal bertopi miring datang menghampiri. Nirwan, begitu ia memperkenalkan diri. Ia bertanya ini-itu, anehnya, dengan logat Sunda yang kental. Baduy yang mendengar aksennya, langsung menembak pertanyaan dengan bahasa Sunda. Nirwan membalas. Oalah ia ternyata berasal dari Tasik! Aku kemudian bercerita 
bahwa kami bukan rombongan resmi yang dibawa Intan. Atas dasar rasa tidak tega karena melihat aku dan kedua sahabatku membuat tenda di sisi pantai, Nirwan menawarkan kebaikannya, memberikan kami 3 piring nasi berhias ikan laut.

"Terima kasih, Kang, suguhannya. Untung ada Kang Nirwan,"

"Harus saling menolong. Apalagi kita sama-sama orang Sunda. Kalau bertemu di luar pulau harus kayak keluarga, atuh,” jawab Nirwana [4](hlm. 143-144)

\section{English translation:}

When I bring out my cutleries out of my backpack, I see this man in a slanted hat approached us. Nirwan, and so he introduced himself. He asked many things with a heavy Sundanese accent. Hearing this, Baduy replied to the man in the Sundanese language. And so Nirwan replied. I get it, he came from Tasik! I told him that we are not a part of Intan's group. Since Nirwan couldn't bear to see my two friends and me making a beach tent, Nirwan offered his help. He brought three platters of rice with fish.

Thank you for your feast, Kang (address term for older brother in Sundanese). We're so lucky to have Kang Nirwan."

"Help each other is a must. Since we are from Sunda, we should treat others as they are our family, especially if meeting with each other in other places," Nirwana replied [4] (p.143-144).

In this excerpt, we can see Nirwan's empathy towards Bung and his friends by giving them meals after knowing that they were making a tent at a beach. Nirwan understood what other people thought with the key idea: "developing others." Simply put, Nirwan understood the feeling of the three friends and reacted to help them out by giving them a platter of rice and fish for each. Nirwan explained that helping others, especially those from the same hometown, is necessary and such people should be treated as a family. The same situation can also be seen in the following excerpt. A young man asked Bung to follow him when Bung was looking for mineral water for breaking the fast. Below is another excerpt of the novel:

"Buka puasa?" Tanyanya.

"Iya."

"Wah, ikut saya kalau begitu."

"ke mana?"

"Mas pasti Musafir. Di sini ada rumah makan yang selalu menyediakan takjil di bulan puasa. Maklum, muslim di sini minoritas, jadi rasa persaudaraan jadi lebih kuat," ia menjelaskan [4] (hlm. 218).

English translation:

"Breaking your fast?" the man asked.

"Yes."

"Alright, then come with me."

"Where?"

"You must be a musafir (traveler). There is a food stall selling takjil during Ramadan nearby. You see, moslem here are minorities, so we have a stronger brotherhood," the young man explained [4] (p.218). 
In the context of social workers, empathy is a situation when a person feels what others think and further processes the feeling cognitively before proceeding to an appropriate and effective response to other people. This concept is in line with the empathy shown in the excerpt above. In a social context, empathy refers to the understanding of others' situation and responding to it through actions. The above dialogue depicts the empathy of a young man who saw Bung moving his lips, reciting a prayer after buying mineral water. The man noticed that Bung was breaking his fast. As the man knew the situation, he asked Bung to follow him to a nearby food stall that provided free meals in Ramadan for Muslim.

\section{Conclusion}

A novel can serve as a medium of character education. Arah Langkah, a novel by Fiersa Besari, tells a story of its empathetic and sympathetic characters. This can serve as a means to instill good characters for the readers. There are other examples of positive traits of role models. For instance, Intan, a character in the novel, traits others fairly and shows empathy at the same time by suggesting solutions to others. Prem is a good example of a person who understands the grief of other characters. She comforts her friend, who was in sorrow. Moreover, Nirwan emphasizes the importance of sharing. The young man offered other people a quick snack or takjil for ending the Ramadan fast. Such affection and responsive attitudes toward other individuals function as a basis of empathy and sympathy, and these traits can be a good role model for the readers.

\section{References}

[1] A. Barnes and P. Thagard, Empathy and Analogy. Waterlo: University of Waterlo, 1999.

[2] V. Rossa and F. D. V, "Studi: 65 Persen Orang Kehilangan Rasa Empati,” [Study: 65 percent of People Loss Their Empathy] 2019. [Online]. Available: https://amp-suaracom.cdn.ampproject.org/v/s/amp.suara.com/lifestyle/2019/04/23/161121/studi-65persen-orang-kehilangan-rasa-empati? [Accessed: 23-Apr-2020].

[3] D. Prabaningrum, S. N. Khasanah, and S. Tyaskyesti, "Karakter Humanis, Aplikasi Prinsip Seperlunya pada Novel Keluarga Cemara 1: Kajian Prinsip Seperlune Suryomentaram," [Humane Character, The Implementation of the Principle of Forbearance in Keluarga Cemara Novel Vol.1: A Study of Suryomentaram's Ideology of Forbearance] J. Sastra Indones., vol. 8, no. 1, pp. 1-5, 2019.

[4] F. Besari, Arah Langkah. Jakarta: Media Kita, 2018.

[5] A. Pramujiono, "Pembelajaran Sastra Multikultural: Menumbuhkan Empati dan Menemukan Jatidiri Bangsa Melalui Pemahaman Keanekaragaman Budaya," [Multicultural Literature Learning: Growing Empathy and Discovering Nation's Selfidentity through the Understanding of Multiculturalism] vol. 8, no. November, pp. 185-194, 2015.

[6] F. J. Cortés Vieco, “'I hate Women. They get on my Nerves' : Dorothy Parker's Poetry of Female Sympathy,” ES Rev. Spanish J. English Stud., vol. 38, no. 38, p. 65, 2017.

[7] V. Aertsen, "Sympathy for Fictional Characters: an Examination of The Factors Involved from a Social Psychology and Cognitive Film Theory Perspective," Doxa Comun., vol. 25, pp. 107-128, 2017. 
[8] A. P. Putri, "NILAI EMPATI DALAM NOVEL LE PETIT NICOLAS ET LES COPAINS KARYA RENÉ GOSCINNY," [THE VALUE OF EMPATHY IN LE PETIT NICOLAS ET LES COPAINS NOVEL BY RENÉ GOSCINNY] Universitas Negeri Jakarta, 2018.

[9] J. Bleicher, Hermeneutika Kontemporer:Hermeneutika sebagai Metode, Filsafat, dan Kritik [Contemporary Hermeneutics: Hermeneutics as a Method, Philosophy, and Critics]. Yogyakarta: Fajar Baru, 2003.

[10] F. Y. Rosita, "Pembelajaran Moral, Etika, dan Karakter Melalui Karya Sastra," [Moral, Ethics, and Character Learning through Literary Works] El-Wasathiya J. Stud.Agama, vol. 1, no. 2, 2013.

[11] F. Besari, Arah Langkah. Jakarta: mediakita, 2018.

[12] S. Ayu, "5 Contoh Faktor Simpati dalam Interaksi Sosial," [5 Examples of the Factor of Sympathy in Social Interactions] PakarKomunikasi.com, 2018. . 